\title{
PLANNING REFORMS IN THE UK
}

\author{
Michael Oxley, Professor \\ De Montfort University Leicester UK and \\ OTB Research Institute for Housing Urban and Mobility Studies, Delft University of Technology, \\ The Netherlands \\ Corresponsal ACE Journal at UK.
}

Key words: Land tax, UK planning laws

A series of changes to the land use planning system in the UK are underway. These are designed to increase the supply of new housing, make planning more responsive to market signals, improve the efficiency of planning processes and promote a better contribution from planning to both enhancing economic growth and protecting the environment. A Bank of England economist, Kate Barker, has been at the centre of proposals designed to achieve these objectives.

The Barker Review of Housing Supply was requested by the Deputy Prime Minister and the Chancellor of the Exchequer in 2003. Their concern was the low level of house building in the UK and the low level of responsiveness of housing production to price rises. This situation, with high rates of house prices rises accompanied by low rates of increase in house building, was seen to suggest a very inelastic supply of new housing compared with other European countries. The Barker Review of Housing Supply was published in $2004^{1}$. It made 36 recommendations to improve housing supply. These included the introduction of a new tax (The Planning-gain Supplement - PGS) on the increased land values resulting from planning permission and several measures to make planning more responsive to market forces.

The government accepted many of the recommendations in the Barker Review including the PGS and consulted on the implementation details ${ }^{2}$. The new tax, which would not come into effect until after 2008, would tax some of the increase in land value, or economic rent, that accrues when planning permission is given. Barker proposed the tax for residential development; the government has suggested that it should apply to all forms of development in the UK. Part of the proceeds would go towards the provision of infrastructure for more housing development.

The new tax would work alongside a reformed system of planning obligations. These obligations, which are termed 'Section 106 agreements' after the section of the relevant legislation, allow local authorities to negotiate arrangements with developers whereby developers contribute to the provision of new infrastructure and other public assets in return for planning permission. This implicit tax will work alongside the new explicit tax (the PGS). If this is to work effectively measures will need to be in place to ensure that the two forms of tax do

\footnotetext{
${ }^{1}$ http://www.hm-treasury.gov.uk/consultations and legislation/barker/consult barker index.cfm

2 http://www.hm-treasury.gov.uk/pre budget report/prebud pbr05/assoc docs/prebud pbr05 adbarker.cfm
} 
not, together, impede the viability of development. A revised government circular (July, 2005) ${ }^{3}$ and new practice guidance (July 2006) ${ }^{4}$ work towards restricting the scale of Section 106 contributions that a local authority might seek and speeding up the negotiation process. To this end the government has published a model template for an agreement ${ }^{5}$.

Another Barker Review, this time a Review of Land Use Planning, was published in December $2006^{6}$. This makes additional proposals to reform the planning system so that planning gives more weight to a balance between economic benefits and environmental issues. There are recommendations for streamlining policies and processes to speed up decision making, new procedures for dealing with major infrastructure projects, enhancing the use of fiscal incentives to ensure efficient land uses and the removal of the need for minor development to obtain permission. The location of future development should, the Review argues, be reconsidered so that land that can be developed with the least adverse environmental or wider social impact is appropriately weighed against areas that need protection because of their environmental value. In this context the green belts that surround some urban areas and cover some 13\% of England should be reassessed. Planning authorities are encouraged to "review their green belt boundaries to ensure they remain relevant and appropriate, and to ensure that planned development takes place in the most sustainable location".

The government has said that it agrees with the overall analysis in the Barker Review of Land Use Planning and it will respond fully to the proposals later in $2007^{7}$.

\footnotetext{
${ }^{3} \mathrm{http}: / / \mathrm{www}$. communities.gov.uk/index.asp?id=1500145

4 http://www.communities.gov.uk/index.asp?id $=1500820$

5 http://www.communities.gov.uk/index.asp?id $=1500832$

6 http://www.communities.gov.uk/index.asp?id $=1163202$

7 http://www.communities.gov.uk/index.asp?id $=1504902$
} 